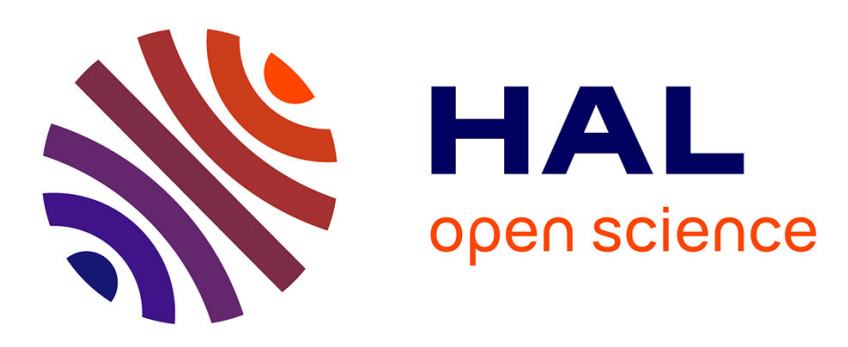

\title{
Thermal cracking of CH3Cl leads to auto-catalysis of deposited coke
}

Eugénie Blaser, Cécile Rosier, Michel Huet, Perrine Chaurand, Christophe Geantet, Stéphane Loridant

\section{- To cite this version:}

Eugénie Blaser, Cécile Rosier, Michel Huet, Perrine Chaurand, Christophe Geantet, et al.. Thermal cracking of $\mathrm{CH} 3 \mathrm{Cl}$ leads to auto-catalysis of deposited coke. Catalysis Science \& Technology, 2021, 11 (2), pp.469-473. 10.1039/d0cy01725f . hal-03159671

\section{HAL Id: hal-03159671 https://hal.science/hal-03159671}

Submitted on 28 Sep 2021

HAL is a multi-disciplinary open access archive for the deposit and dissemination of scientific research documents, whether they are published or not. The documents may come from teaching and research institutions in France or abroad, or from public or private research centers.
L'archive ouverte pluridisciplinaire HAL, est destinée au dépôt et à la diffusion de documents scientifiques de niveau recherche, publiés ou non, émanant des établissements d'enseignement et de recherche français ou étrangers, des laboratoires publics ou privés. 
Received 00th January 20xx, Accepted 00th January 20xx DOI: $10.1039 / \times 0 \times x 00000 x$

\section{Thermal cracking of $\mathrm{CH}_{3} \mathrm{Cl}$ leads to auto-catalysis of deposited coke}

\author{
Eugénie Blaser, ${ }^{a, b} *$ Cécile Rosier, ${ }^{b}$ Michel Huet, ${ }^{b}$ Perrine Chaurand , c \\ Christophe Geantet, ${ }^{a}$ and Stéphane Loridant, a *
}

Thermal cracking of $\mathrm{CH}_{3} \mathrm{Cl}$ was studied on $\mathrm{SiO}_{2}$ particles, at 0.4 $\mathrm{MPa}$, from 375 to $550{ }^{\circ} \mathrm{C}$. The cracking occurs for temperatures higher than $400{ }^{\circ} \mathrm{C}$ and leads to the formation of solid coke composed of chlorinated hydrocarbons. This coke is active as it catalyses the $\mathrm{CH}_{3} \mathrm{Cl}$ cracking at temperatures lower than those required for the thermal cracking and leads to the formation of $\mathrm{HCl}, \mathrm{CH}_{4}$ and hydrocarbons. $\mathrm{Cl}$ present in this coke is reponsible for its activation.

In 2019, 2.4 million metric tons of silicones were synthesized ${ }^{1}$ and used in a wide range of application (transportation, electronics, energy,....)..$^{2,3}$ Therefore, it is crucial to optimize each major step of the silicones production such as the direct synthesis, also called the Müller-Rochow reaction and given in eqn. 1.

$\mathrm{Si}(\mathrm{s})+2 \mathrm{CH}_{3} \mathrm{Cl}(\mathrm{s}) \rightarrow\left(\mathrm{CH}_{3}\right)_{2} \mathrm{SiCl}_{2}(\mathrm{~g})$

(eqn. 1)

In this reaction, solid silicon is mixed with gaseous $\mathrm{CH}_{3} \mathrm{Cl}$ at temperature and pressure ranging between $265-310^{\circ} \mathrm{C}$ and 2-7 bar, respectively, in fluidized-bed reactors. ${ }^{4,5}$ Copper-based catalysts are usually used to increase the selectivity to $\left(\mathrm{CH}_{3}\right)_{2} \mathrm{SiCl}_{2}$ and give a long steady state. $6,7,8$ However, the Direct Synthesis suffers from a side-reaction during which the $\mathrm{CH}_{3} \mathrm{Cl}$ reagent cracks and forms $\mathrm{H}_{2}, \mathrm{HCl}, \mathrm{CH}_{4}$ as well as solid and liquid hydrocarbons. ${ }^{9,10}$ These hydrocarbons, usually referred to as coke, may deposit on the active sites, ${ }^{11}$ reduce the productivity of $\left(\mathrm{CH}_{3}\right)_{2} \mathrm{SiCl}_{2}$ leading to the deactivation. ${ }^{12}$ A X-ray micro computed-tomography (micro-CT) image of coke covering the metals-based phases which catalyzed the Direct Synthesis is shown in Figure 1.

a. Univ Lyon, Université Claude Bernard-Lyon 1, CNRS, IRCELYON-UMR 5256, $2 a v$. A.Einstein, F-69626 Villeurbanne Cedex, France, email :

stephane.loridant@ircelyon.univ-lyon1.fr and eugenie.blaser@elkem.com

b. ELKEM SILICONES - 55 av Frères Perret 69190 SAINT FONS - France

c. Aix Marseille Univ, CNRS, IRD, INRA, Coll France, CEREGE, Aix-en-Provence, France

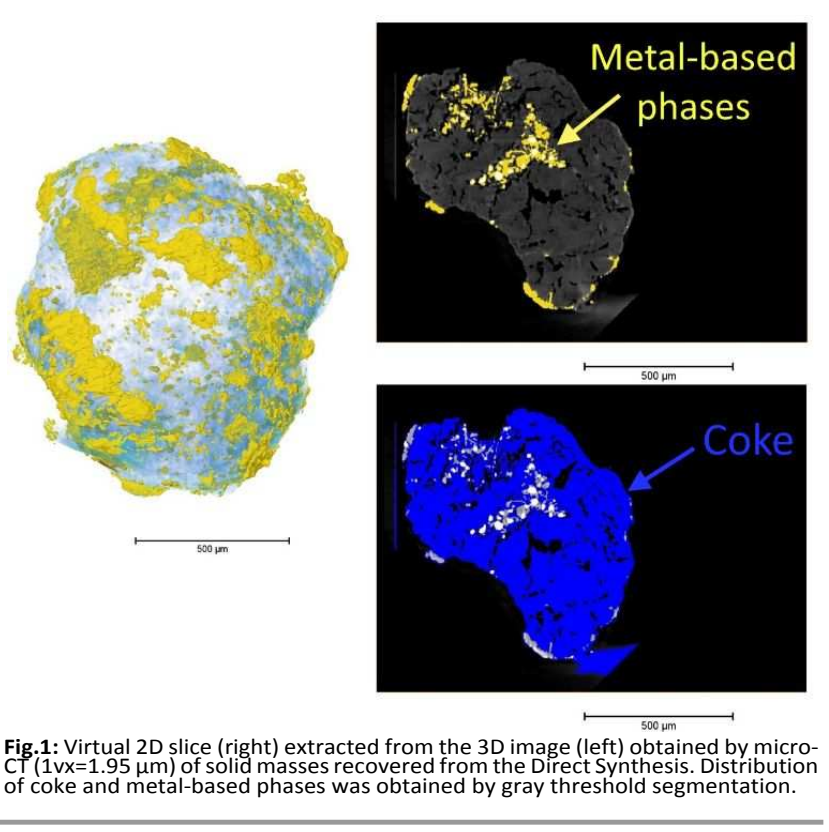

High temperatures may cause the thermal cracking of $\mathrm{CH}_{3} \mathrm{Cl}$. This type of cracking was studied by several authors who reported a radical mechanism of $\mathrm{CH}_{3} \mathrm{Cl}$ cracking leading to $\mathrm{CH}_{3}{ }^{\bullet}$ and $\mathrm{Cl}^{\bullet}$ radicals. ${ }^{13-16}$ However, they used experimental conditions different from those of the Direct Synthesis with temperature much higher than $265-310{ }^{\circ} \mathrm{C}$. Therefore, their conclusions on thermal cracking may not be applied to what occurs in the Direct Synthesis.

In the present work, thermal cracking of $\mathrm{CH}_{3} \mathrm{Cl}$ was studied with experimental conditions as close as possible to those of the Direct Synthesis, between 375 and $550{ }^{\circ} \mathrm{C}$. To our best knowledge, no study of thermal cracking in this range of temperature has been reported yet. For each cracking test 
(experimental conditions detailed in the $\mathrm{ESI}$ ), the selectivity values to $\mathrm{H}_{2}, \mathrm{CH}_{4}$, coke and other hydrocarbons with $\mathrm{C} \leq 4$ were determined. The purposes of this work were to determine the onset temperature for the $\mathrm{CH}_{3} \mathrm{Cl}$ cracking and the reaction of cracking with experimental conditions close to those applied for the Direct Synthesis. Besides, the coke formed by thermal cracking was characterized by $\mathrm{C}$ and $\mathrm{H}$ elemental analysis, Raman spectroscopy and XRF (methods in the ESI) and tested to determine its catalytic role on the cracking reaction itself.

The tests of $\mathrm{CH}_{3} \mathrm{Cl}$ cracking were performed in a fixed-bed reactor (see details in the ESI) with glass beads and silica particles as surface to initiate radicals as well as on black carbon (see materials in the ESI).

The first series of thermal cracking tests was performed on the glass beads and Figure 2 plots the evolution of the $\mathrm{CH}_{3} \mathrm{Cl}$ conversion with time. The cracking starts between 400 and $450{ }^{\circ} \mathrm{C}$ suggesting it does not occur for the Direct Synthesis performed around $300{ }^{\circ} \mathrm{C}$. Nevertheless, in industrial reactors, insufficient fluidisation may lead to the formation of hot spots ${ }^{17}$ where thermal cracking could still occur. This highlights that, with optimal conditions of fluidization, no thermal cracking occurs whereas with inefficient fluidization, coke may be formed by thermal cracking leading to the deactivation and to a production loss.

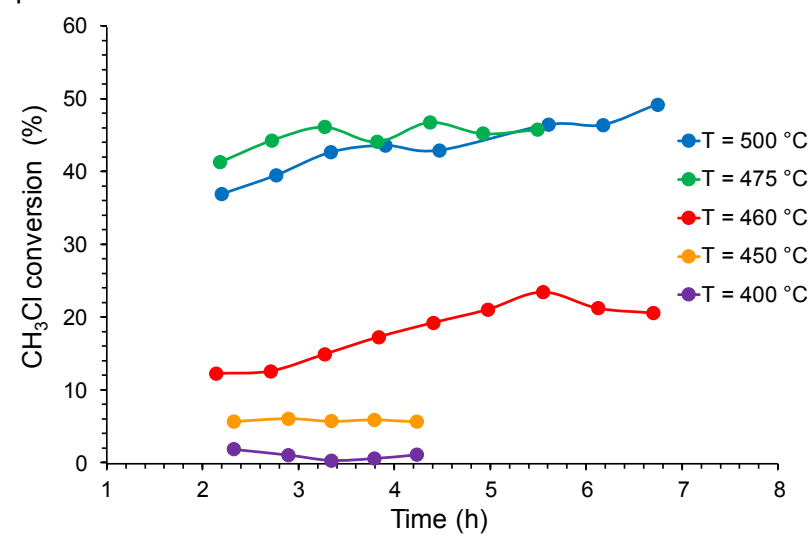

Fig. 2: Conversion of $\mathrm{CH}_{3} \mathrm{Cl}$ for thermal cracking on $0.8 \mathrm{~g}$ of glass beads $\left(2 \mathrm{~m}^{2} / \mathrm{kg}\right.$ ) at $\mathrm{X}\left(\mathrm{CH}_{3} \mathrm{Cl}\right)$ conversion was estimated at $\pm 0.11 \times \mathrm{X}\left(\mathrm{CH}_{3} \mathrm{Cl}\right)$.

Above $475{ }^{\circ} \mathrm{C}$, the $\mathrm{CH}_{3} \mathrm{Cl}$ conversion did not increase with the temperature. This limitation is attributed to the small surface of glass beads. Thus, $\mathrm{SiO}_{2}$ particles with a higher specific surface area $\left(310 \mathrm{~m}^{2} / \mathrm{g}\right)$ were used to study the thermal cracking as well.

The activation energy was determined from the rates of $\mathrm{CH}_{3} \mathrm{Cl}$ consumption at different temperatures (Table 1 with rates in the range of $\left.10^{-7} \mathrm{~mol} / \mathrm{s}\right)$. The evolution of $\ln (r)$ as function of $1 / \mathrm{T}$ is reported in Figure 3, with $r$ the consumption rate of $\mathrm{CH}_{3} \mathrm{Cl}$. Only the temperatures 450,460 and $475{ }^{\circ} \mathrm{C}$ were used for the graph. The rate obtained at $400{ }^{\circ} \mathrm{C}$ was too low to be precisely measured and limitation occurred at $500{ }^{\circ} \mathrm{C}$ due to the low specific area. From results reported in Table 1 , the activation energy was determined at $338 \mathrm{~kJ} / \mathrm{mol}$. This result is in the range of activation energy experimentally determined for the thermal cracking: 305 and $501 \mathrm{~kJ} / \mathrm{mol} .{ }^{18}$ Moreover, the result is close to the dissociation energy of the $\mathrm{C}-\mathrm{H}$ bond and is lower than the one of $\mathrm{C}-\mathrm{Cl}$ in $\mathrm{CH}_{3} \mathrm{Cl}, 339$ and $423 \mathrm{~kJ} / \mathrm{mol}$ respectively. ${ }^{19}$ Such result is consistent with a homolytic bond breaking, leading to the radicals formation. However, it does not necessarily mean that only the $\mathrm{C}-\mathrm{H}$ bond breaks and not $\mathrm{C}-\mathrm{Cl}$. $\mathrm{CH}_{3} \mathrm{Cl}$ cracking by $\mathrm{C}-$ $\mathrm{Cl}$ bond breaking was also reported. ${ }^{13-15}$

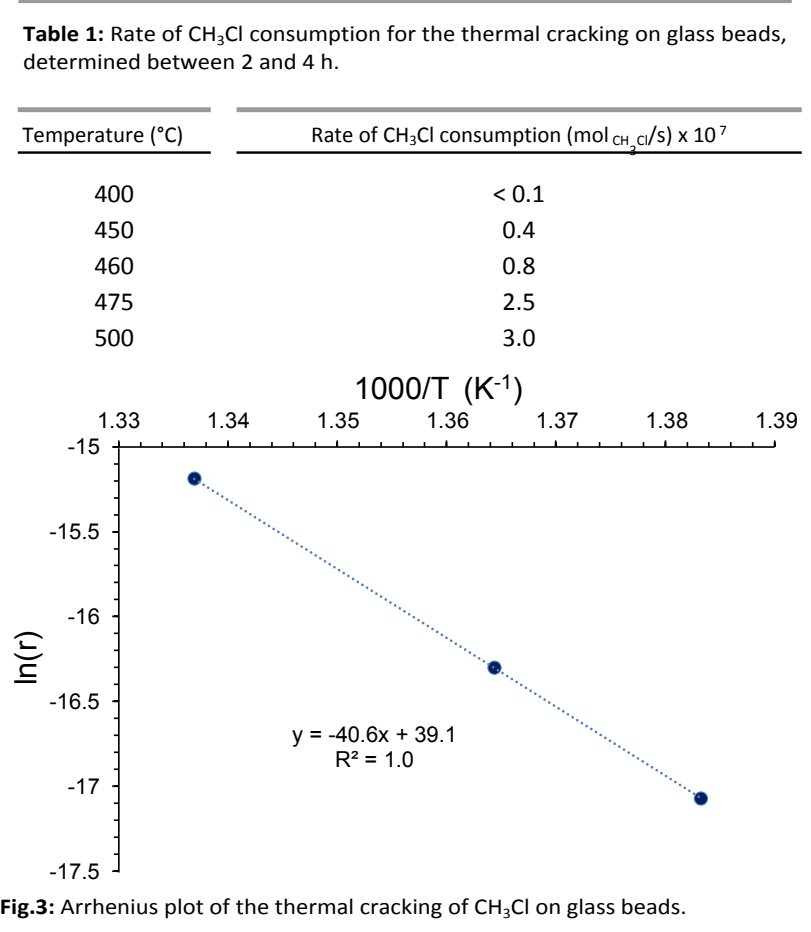

The second series of $\mathrm{CH}_{3} \mathrm{Cl}$ cracking was performed on silica particles and Figure 4 displays the evolution of $\mathrm{CH}_{3} \mathrm{Cl}$ conversion for these tests. Like the glass beads, the cracking starts between 400 and $450^{\circ} \mathrm{C}$.

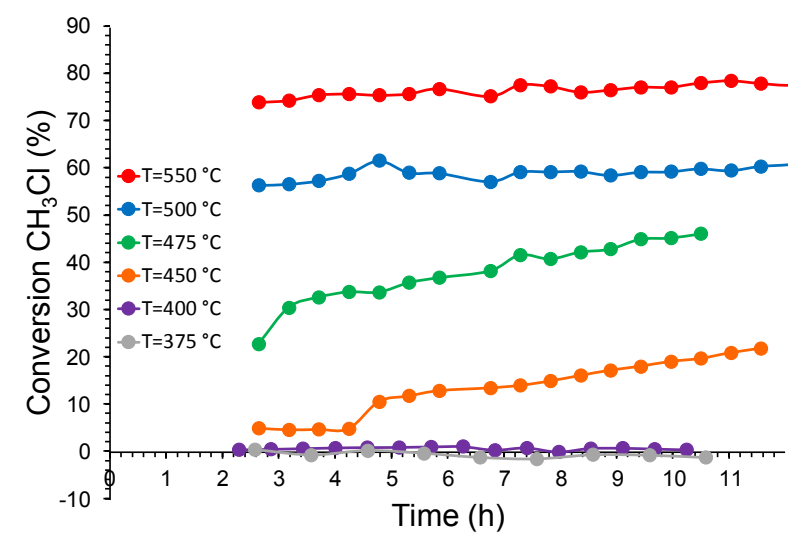

Fig.4: $\mathrm{CH}_{3} \mathrm{Cl}$ conversion for thermal cracking on $\mathrm{SiO}_{2}$ particles from 375 to $5500^{\circ} \mathrm{C}$ with $0.8 \mathrm{~g}$ of mass loaded, at $0.4 \mathrm{Mbar}$. Residence time $=0.3 \mathrm{~min}^{2}$. The

The cokes obtained from thermal cracking at $450,500,550^{\circ} \mathrm{C}$ and from the Direct Synthesis have a $\mathrm{H} / \mathrm{C}$ molar ratio of 1.0, 0.2, 0.1 and 0.5 , respectively. This suggests the formation of hydrogen-poor coke, which was confirmed by Raman 
spectroscopy, displayed in Figure 5. The G-band around 1575$1580 \mathrm{~cm}^{-1}$ corresponds to a vibrational mode of graphitic plan with $E_{2 g}$ symmetry. ${ }^{20,21}$ The D-band, around $1350 \mathrm{~cm}^{-1}$ is due to a vibrational mode with $A_{1 \mathrm{~g}}$ symmetry and is related to defects or heteroatoms present in the graphitic plans. ${ }^{21}$ The ratio Area $(\mathrm{D}$ - band $)$ $\overline{\text { Area(G-band) }}$ is related to the order degree of graphite. ${ }^{21}$ This ratio is 2.8 and 3.0 for coke from thermal cracking coke and Direct Synthesis, respectively. The nature of coke obtained by thermal cracking is like the one formed during the Direct Synthesis.

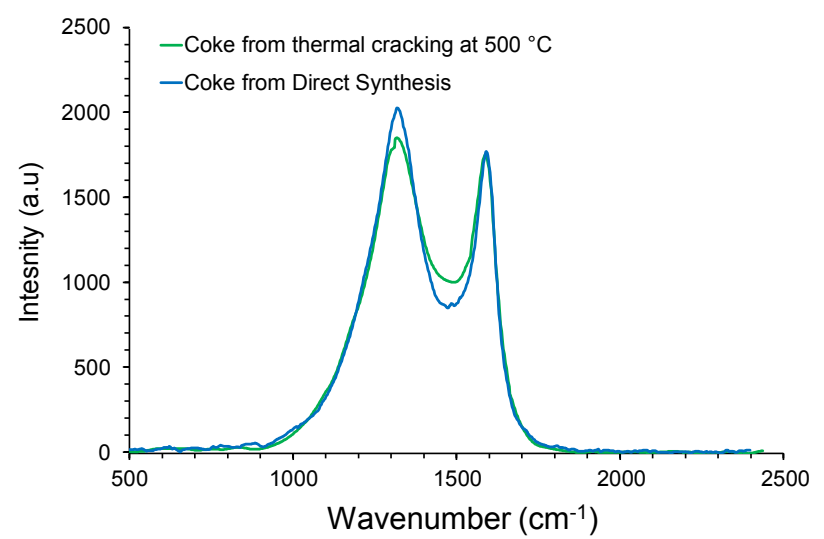

Fig.5: Raman spectra of coke from thermal cracking $\left(T=500{ }^{\circ} \mathrm{C}\right)$ and from Direct Synthesis.

According to Figure 4, the conversion of $\mathrm{CH}_{3} \mathrm{Cl}$ tends to increase with time, suggesting the formation of another contributor to the cracking. To estimate the influence of this other cracking contributor, the rate of $\mathrm{CH}_{3} \mathrm{Cl}$ consumption and the activation energy between 2 and $4 \mathrm{~h}$ and between 8 and $10 \mathrm{~h}$ under flow were compared. However, the reaction rate determined at $550{ }^{\circ} \mathrm{C}$ was not considered for the calculation of the activation energy because it slowly increases with time suggesting a diffusion resistance. Figure 6 plots the evolution of $\ln (r)$ as function of $1 / \mathrm{T}$, with $\mathrm{r}$ the $\mathrm{CH}_{3} \mathrm{Cl}$ consumption rate and the activation energy values are reported in Table 2 . The activation energy decreases during the reaction and is much lower than the one obtained with glass beads (i.e. $338 \mathrm{~kJ} / \mathrm{mol}$ ). Such observation suggests the formation of a catalyst during the cracking.

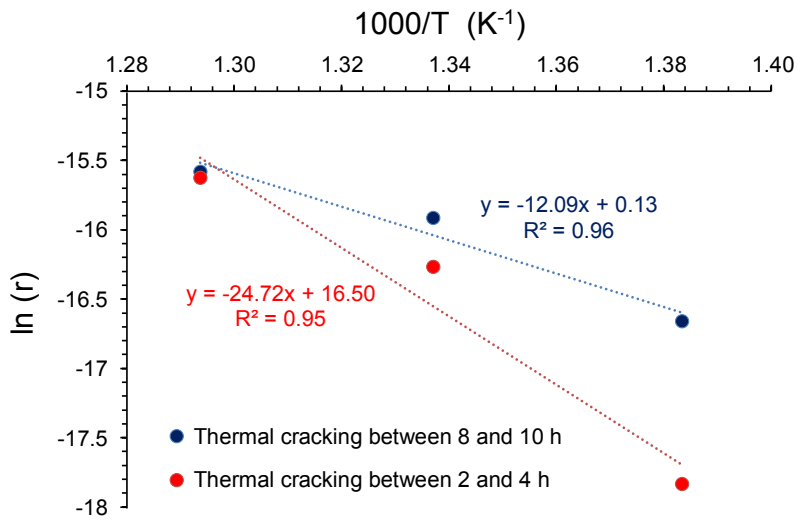

Fig.6: Arrhenius plot corresponding to the beginning and the end of the thermal cracking of $\mathrm{CH}_{3} \mathrm{Cl}$ on $\mathrm{SiO}_{2}$ particles.
Table 2: Rate of $\mathrm{CH}_{3} \mathrm{Cl}$ consumption for the thermal cracking on $0.8 \mathrm{~g}$ of $\mathrm{SiO}_{2}$ particles, $\mathrm{P}=0.4 \mathrm{Mbar}$, residence time $=0.3 \mathrm{~min}$.

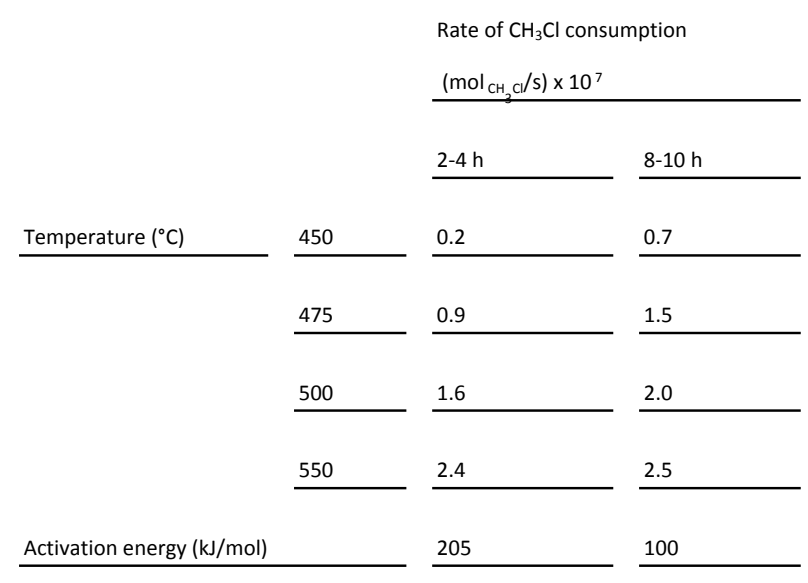

To confirm the hypothesis of an auto-catalytic cracking, a reaction was performed on $\mathrm{SiO}_{2}$ particles at $500{ }^{\circ} \mathrm{C}$ and the temperature was decreased to $400{ }^{\circ} \mathrm{C}$ after $15 \mathrm{~h}$. Figure 7 compares the $\mathrm{CH}_{3} \mathrm{Cl}$ conversion during this test and the one on $\mathrm{SiO}_{2}$ at $400{ }^{\circ} \mathrm{C}$ on fresh silica. While $\mathrm{CH}_{3} \mathrm{Cl}$ did not crack on fresh silica at $400{ }^{\circ} \mathrm{C}$, it did on $\mathrm{SiO}_{2}$ after thermal cracking at $500{ }^{\circ} \mathrm{C}$, confirming the formation of active compounds for $\mathrm{CH}_{3} \mathrm{Cl}$ cracking. Similar results were obtained when the thermal cracking was first performed at 450 and $550{ }^{\circ} \mathrm{C}$ instead of 500 ${ }^{\circ} \mathrm{C}$. These results are provided in Figure S1 (see ESI).

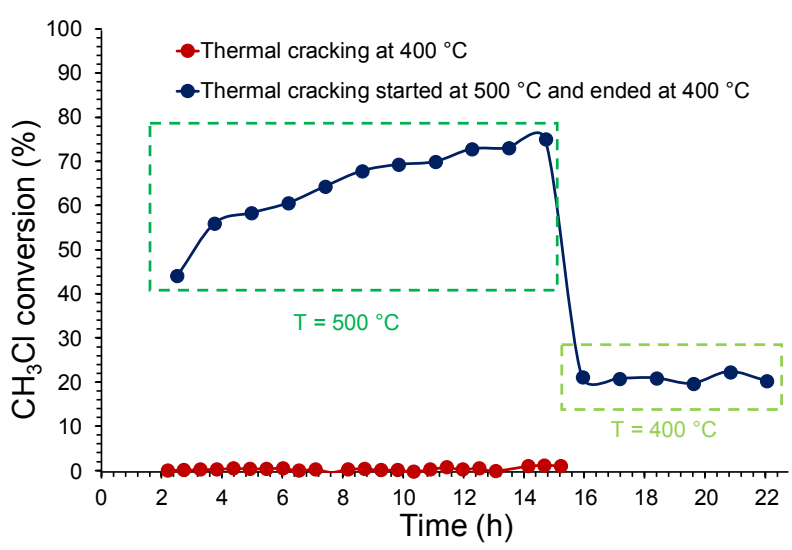

Fig.7: Conversion of $\mathrm{CH}_{3} \mathrm{Cl}$ for thermal cracking on $0.8 \mathrm{~g}$ of $\mathrm{SiO}_{2}$ started at $500{ }^{\circ} \mathrm{C}$ and ended at $400^{\circ} \mathrm{C}$, at $0.4 \mathrm{Mbar}$ and with a residence time of $0.3 \mathrm{~min}$.

To determine whether silica texture contributes or not to this phenomenon, the same test of cracking was performed on larger quartz particles $(1 \mathrm{~mm})$. After $15 \mathrm{~h}$ of thermal cracking at $500{ }^{\circ} \mathrm{C}$, the temperature was reduced at $400{ }^{\circ} \mathrm{C}$ and $\mathrm{CH}_{3} \mathrm{Cl}$ did crack. This suggests that $\mathrm{SiO}_{2}$ was not the catalyst for the $\mathrm{CH}_{3} \mathrm{Cl}$ cracking since the geometric surface of quartz was too small to generate active sites. Therefore, it appears that coke formed by the thermal cracking further catalyzes the cracking at $400^{\circ} \mathrm{C}$. Hence, there is an auto-catalytic phenomenon occurring during the thermal cracking caused by coke and two origins of the cracking have to be distinguished: thermal and auto-catalytic, 
with a respective contribution dependent on the temperature. For the industrial Direct Synthesis, it means that coke catalyses the $\mathrm{CH}_{3} \mathrm{Cl}$ cracking at temperature lower than those required for the thermal cracking.

Tran et al. reported an auto-catalytic effect for pyrolysis of $\mathrm{CH}_{3} \mathrm{Cl}$ on quartz particles but with experimental conditions far from those of the Direct Synthesis (i.e. between 747 and $987^{\circ} \mathrm{C}$, at $1 \mathrm{~atm}) .{ }^{18}$ However, they did not investigate the nature of the catalyst. To our best knowledge, such catalytic activity at $400^{\circ} \mathrm{C}$ of coke formed during the $\mathrm{CH}_{3} \mathrm{Cl}$ cracking was not previously reported.

The $\mathrm{CH}_{3} \mathrm{Cl}$ cracking was performed on black carbon at $400{ }^{\circ} \mathrm{C}$ and no cracking was observed. To understand the difference in the activity of black carbon and coke at $400{ }^{\circ} \mathrm{C}$, both solids were compared by Raman spectroscopy (Figure 8). Based on these results, no significant difference was observed between the two solids. In addition, the molar ratio $\mathrm{H} / \mathrm{C}$ of coke from thermal cracking and black carbon are 0.2 and 0.1 , respectively. These results did not explain the difference in activity of both solids.

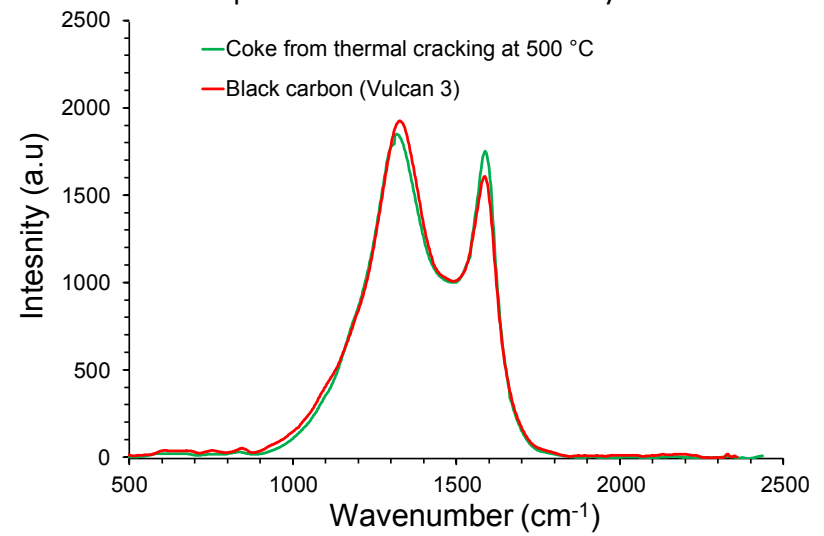

Fig.8: Raman spectra of black carbon and thermal coke obtained by $\mathrm{CH}_{3} \mathrm{Cl}$ therma cracking on $\mathrm{SiO}_{2}$ particles at $500^{\circ} \mathrm{C}$.

XRF performed on cokes obtained at 450,500 and $550{ }^{\circ} \mathrm{C}$ showed the presence of $\mathrm{Cl}$ between 1.0 and $7.6 \mathrm{wt} \%$, while the initial $\mathrm{Cl}$ content from the $\mathrm{SiO}_{2}$ support is $0.1 \mathrm{wt} \%$. $\mathrm{Cl}$ may acidify the coke, and thus, lead to the formation of acidic sites. Chlorination of activated carbon by $\mathrm{Cl}_{2}{ }^{22}$ or by $\mathrm{HCl}^{23}$ is reported to decrease its PZC (Potential of Zero Charge). This means that the acidity of activated carbon increases which is consistent with the hypothesis suggested above. Besides, the higher the temperature for the chlorination, the higher the $\mathrm{Cl}$ content in the final solid. 22,24

The $\mathrm{CH}_{3} \mathrm{Cl}$ consumption rate determined at $400{ }^{\circ} \mathrm{C}$ of the cokes obtained by thermal cracking at 450,500 and $550{ }^{\circ} \mathrm{C}$ is related to their initial $\mathrm{Cl}$ content, as shown in Figure 9. This confirms the active role of $\mathrm{Cl}$ in the auto-catalytic cracking.

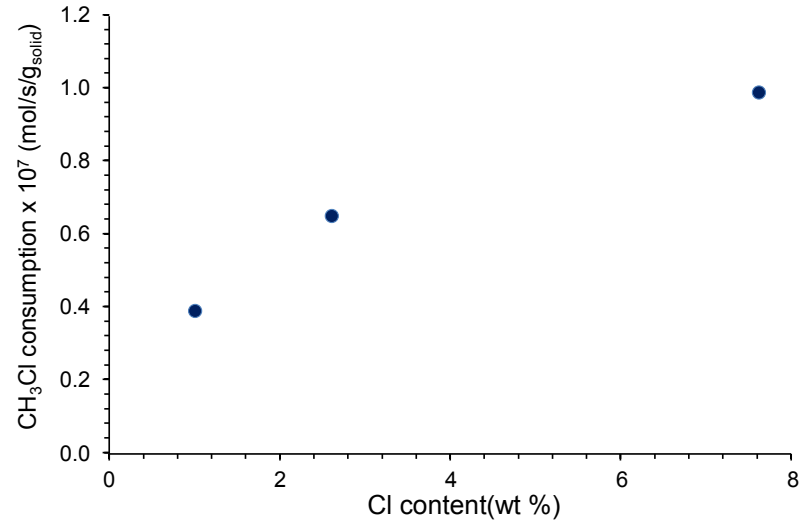

Fig.9: $\mathrm{CH}_{3} \mathrm{Cl}$ consumption rate at $400{ }^{\circ} \mathrm{C}$ on thermal coke as function of the $\mathrm{C}$ Fig.9: $\mathrm{CH}_{3} \mathrm{Cl}$ consumption rate at $400{ }^{\circ} \mathrm{C}$ on thermal coke as function of the
content in these cokes obtained by thermal cracking at 450,500 and $5500^{\circ} \mathrm{C}$.

To determine the auto-catalytic reaction of $\mathrm{CH}_{3} \mathrm{Cl}$, focus was put on the selectivity. Thermal cracking at $550{ }^{\circ} \mathrm{C}$ was performed to produce a high amount of thermal coke which generates autocatalytic cracking. The values of selectivity obtained for the whole reaction were as follows: $\mathrm{S}\left(\mathrm{H}_{2}\right), \mathrm{S}\left(\mathrm{C}_{2}\right), \mathrm{S}\left(\mathrm{C}_{3}\right), \mathrm{S}\left(\mathrm{C}_{4}\right)<1 \%$, $\mathrm{S}\left(\mathrm{CH}_{4}\right)=44 \%, \mathrm{~S}($ coke $)=56 \%, \mathrm{~S}(\mathrm{HCl}) \approx 100 \%$. Therefore, the reaction eqn. 2 is suggested for the auto-catalytic cracking of $\mathrm{CH}_{3} \mathrm{Cl}$ on coke.

$\mathrm{CH}_{3} \mathrm{Cl} \rightarrow 1 / 2 \mathrm{CH}_{4}+1 / 2 \mathrm{C}+\mathrm{HCl}$

Interestingly, this reaction is reported to be the reaction of thermal cracking at temperatures lower than $150{ }^{\circ} \mathrm{C}$, based on thermodynamic simulations. ${ }^{10}$ However, since the thermal cracking starts between 400 and $450^{\circ} \mathrm{C}$, it is limited by kinetic below $150^{\circ} \mathrm{C}$ but is catalyzed by chlorinated coke at $400{ }^{\circ} \mathrm{C}$.

\section{Conclusions}

The thermal cracking of $\mathrm{CH}_{3} \mathrm{Cl}$ on inert particles starts between 400 and $450{ }^{\circ} \mathrm{C}$. Therefore, thermal cracking may occur during the industrial Direct Synthesis in hot spots, usually formed with inefficient fluidization. It leads to the formation of an active coke which further catalyses the cracking at $400{ }^{\circ} \mathrm{C}$ leading to formation of additional coke (autocatalytic phenomenon). This work also evidenced that coke contains $\mathrm{Cl}$ which is at the origin of its catalytic activity.

\section{Conflicts of interest}

There are no conflicts to declare.

\section{Acknowledgment}

Dr. Cécile Rosier and Michel Huet are acknowledged for initiating this project. Eugénie Blaser thanks Elkem for Ph.D. grant.

\section{Notes and references}


1 https://www.imarcgroup.com/silicones-market

2 C. Corden, B. Tyrer, H. Menadue, J. Calero, J. Dade and R. Leferink, Socio-economic evalution of the global silicones industry, 2013, 4-7.

3 W.Kalchuer and B.Pachaly, Handbook of Heterogeneous Catalysis, 2008, 2635-2647.

4 B. Kanner and K. Lewis, Catalyzed direct reactions of silicon, Elsevier, 1993.

5 J. Mohsseni, J. Gross, K. Mautner, N. Sofina and T. Wuestenfeld, US Patent 0305939, Method for the Direct Synthesis of Methylchlorosilanes in Fluidized-bed reactors 2017.

6 C. Wang, G. Wang and J. Wang, Chin. J. Chem. Eng., 2014, 22, 13, 299-304.

7 A.D. Gordon, B.J. Hinch and D.R. Strongin, J. Catal., 2009, 266, 291-298.

8 Y. Zang, J. Li, H. Lui, Z. Zhong and F. Sun, Chem. Cat. Chem, 2019, 12, 2757-2779.

9 V. Bazant, Pure Appl. Chem., 1966, 13, 1313, 313-326,.

11 C. Bartholomew, Appl. Catal. A, 2001, 212, 17-60.

12 J. Jokilk and V. Bazant, Collect. Czech Chem. C, 1961, 26, 417-426.

13 A. Shilov and R. Sabirova, Russ. J. Phys. Chem. A, 1959, 34, 408-411.

14 O. Kondo, K. Saito and I. Murakami, Chem. Soc. Jpn., 1980, 53, 2133-2140.

15 M. Weissman and S. W. Benson, Int. J. Chem. Kinet., 1984, 16, 307-333.

16 Y.-S. Won, J. Ind. Eng. Chem., 2007, 3, 400-405.

17 Z. Jia, C. Zhang, D. Cai, E. Blair, W. Qian and F. Wei, RSC Adv., 2017, 7, 20186-20191.

18 T. Tran and S. Senkan, Ind. Eng. Chem. Res., 1994, 33, 3240.

19 J. A. Dean, Lange's Handbook of Chemistry, McGraw-Hilln, Inc, 1999, 308-310.

20 A. Cuesta, P. Dhamelincourt and J. Laureyns, Carbon, 1994, 32, 18, 1523-1532.

21 M. Pimenta, G. Dresselhaus, M. Dresselhaus, L. Cançao, A. Jorio and R. Saito, Phys. Chem. Chem. Phys., 2007, 9, 12761291.

22 A.-F. Perze-Cadenas, F. Maldonado-Hodar and M. MorenoCastill, Carbon, 2003, 41, 473-478.

23 M. Evans, E. Halliop, S. Liang and J. MacDonald, Carbon, 1988, 36, 111, 1677-1682.

24 R. Hall and R. Holmes, Carbon, 1993, 31, 16, 881-886. 
Electronic Supplementary Information for

Thermal cracking of $\mathrm{CH}_{3} \mathrm{Cl}$ leads to auto-catalysis of deposited coke

Eugénie Blaser, Cécile Rosier, Michel Huet, Perrine Chaurand, Christophe Geantet and Stéphane Loridant

Univ Lyon, Université Claude Bernard Lyon 1, CNRS, IRCELYON, F-69626, Villeurbanne, France 


\section{$\underline{\text { Materials }}$}

As the thermal cracking of $\mathrm{CH}_{3} \mathrm{Cl}$ was reported to be a radical route, two types of inert surface were used to initiate the $\mathrm{CH}_{3}{ }^{\bullet}$ and $\mathrm{Cl}{ }^{\bullet}$ radicals. The first one consisted of glass beads purchased from Carl Roth (Ref. A555.1) with a size ranging between 1.25 and $1.65 \mathrm{~mm}$ and with a geometric area of $2 \mathrm{~m}^{2} / \mathrm{kg}$. The second inert surface was $\mathrm{SiO}_{2}-432$ from Grace Davison, crushed and sieved between 50 and $400 \mu \mathrm{m}$ before the $\mathrm{CH}_{3} \mathrm{Cl}$ cracking. Its specific surface area (SSA) was $310 \mathrm{~m}^{2} / \mathrm{g}$ and it contained $0.1 \mathrm{wt} \%$ of $\mathrm{Cl}$. Black Carbon was a Vulcan 3 (Cabot) powder sample with SSA of $75 \mathrm{~m}^{2} / \mathrm{g}$.

\section{Catalytic testing for the thermal cracking}

The $\mathrm{CH}_{3} \mathrm{Cl}$ cracking tests were performed in a fixed-bed reactor with a height and a diameter of 3 and $1 \mathrm{~cm}$, respectively. All the tests were performed at a pressure of $0.4 \mathrm{MPa}$ (similar to the DS) and six temperatures were set: $375,400,450,475,500$ and $550{ }^{\circ} \mathrm{C}$.

Before each test, the reactor was flushed under $100 \mathrm{mls} / \mathrm{min}$ of pure Ar at atmospheric pressure while temperature was increased from room temperature to the desired one with a rate of $5{ }^{\circ} \mathrm{C} / \mathrm{min}$ and maintained under $\mathrm{Ar}$ for $1 \mathrm{~h}$. The argon flush was then stopped. $\mathrm{CH}_{3} \mathrm{Cl} / \mathrm{Ar}$ $(10 / 90)$ mixed with $N_{2}$, with respective flow of 5.22 and $3.18 \mathrm{mls} / \mathrm{min}$, were introduced during ca $15 \mathrm{~h} . \mathrm{N}_{2}$ was used as an internal standard.

During the $\mathrm{CH}_{3} \mathrm{Cl}$ cracking, the output gases $\mathrm{N}_{2}, \mathrm{CH}_{3} \mathrm{Cl}, \mathrm{H}_{2}, \mathrm{CH}_{4}, \mathrm{C}_{2} \mathrm{H}_{6}, \mathrm{C}_{2} \mathrm{H}_{4}, \mathrm{C}_{3} \mathrm{H}_{8}, \mathrm{C}_{3} \mathrm{H}_{6}$, n-butane and isobutene were analyzed by Shimazu GC-2014 and treated with the LabSolutions software. $\mathrm{HCl}$ selectivity was determined using a trap with $\mathrm{NaOH}$ and by measuring the initial and final $\mathrm{pH}$.

The selectivity to A product was calculated by (eqn. S1).

Sel $(A)=\frac{n(A)_{\text {output }}}{n\left(\mathrm{CH}_{3} \mathrm{Cl}\right)_{\text {input }}-\mathrm{n}\left(\mathrm{CH}_{3} \mathrm{Cl}\right)_{\text {output }}} \times 100$

where $n(A)_{\text {output }}$ corresponds to the amount of $A$ product at the output of the fixed bed reactor and $n\left(\mathrm{CH}_{3} \mathrm{Cl}\right)_{\text {input }}$ and $n\left(\mathrm{CH}_{3} \mathrm{Cl}\right)_{\text {output }}$ correspond to the amount of $\mathrm{CH}_{3} \mathrm{Cl}$ reagent on the input and output of the fixed bed reactor, respectively.

The consumption rate of $\mathrm{CH}_{3} \mathrm{Cl}$ was calculated by (eqn. S2) with $\mathrm{X}\left(\mathrm{CH}_{3} \mathrm{Cl}\right)$ the conversion of $\mathrm{CH}_{3} \mathrm{Cl}$ and $\mathrm{F}\left(\mathrm{CH}_{3} \mathrm{Cl}\right)$ the input flow of $\mathrm{CH}_{3} \mathrm{Cl}\left(\mathrm{mol}^{-1} \mathrm{~s}^{-1}\right)$. A first-order of reaction was assumed for the calculation of the reaction rate, because of the low partial pressure of $\mathrm{CH}_{3} \mathrm{Cl}$. 
$\mathrm{r}_{\mathrm{CH}_{3} \mathrm{Cl} \text { consumption }}=\mathrm{X}\left(\mathrm{CH}_{3} \mathrm{Cl}\right) \times \mathrm{F}\left(\mathrm{CH}_{3} \mathrm{Cl}\right)$

(eqn. S2)

The activation energy of thermal cracking was determined from the rates determined after two hours of reaction assuming a first order reaction. For glass beads, the experiments performed at $400{ }^{\circ}$ and $500{ }^{\circ} \mathrm{C}$ were discarded because the conversion was too low and limitation occurred, respectively. For silica particles, the experiment performed at $550{ }^{\circ} \mathrm{C}$ was not considered for the calculation because diffusion resistance was suspected.

\section{Characterization methods}

In addition to gases, the amount of coke deposited on silica was determined by elemental analysis on carbon with a Thermo Scientific, Flash 200 organic elemental analyzer.

Raman spectra reported in this work were performed at ambient atmosphere with a LabRam HR (Jobin Yvon-Horiba) spectrometer. The exciting line at $633 \mathrm{~nm}$ of a He-Ne laser was used. The power measured at the sample was around $1 \mathrm{~mW}$. The spatial resolution is ca 4 microns and the spectral resolution is $4 \mathrm{~cm}^{-1}$. For each sample, the spectrum corresponds to the mean of ca 20 spectra recorded on different analysis areas.

The X-Ray Fluorescence analysis was performed with a Panalytical, Epsilon 4 instrument equipped with an $\mathrm{Ag}$ source. The $\mathrm{Cl}$ content was determined from a semi-quantitative method (Omnian). 


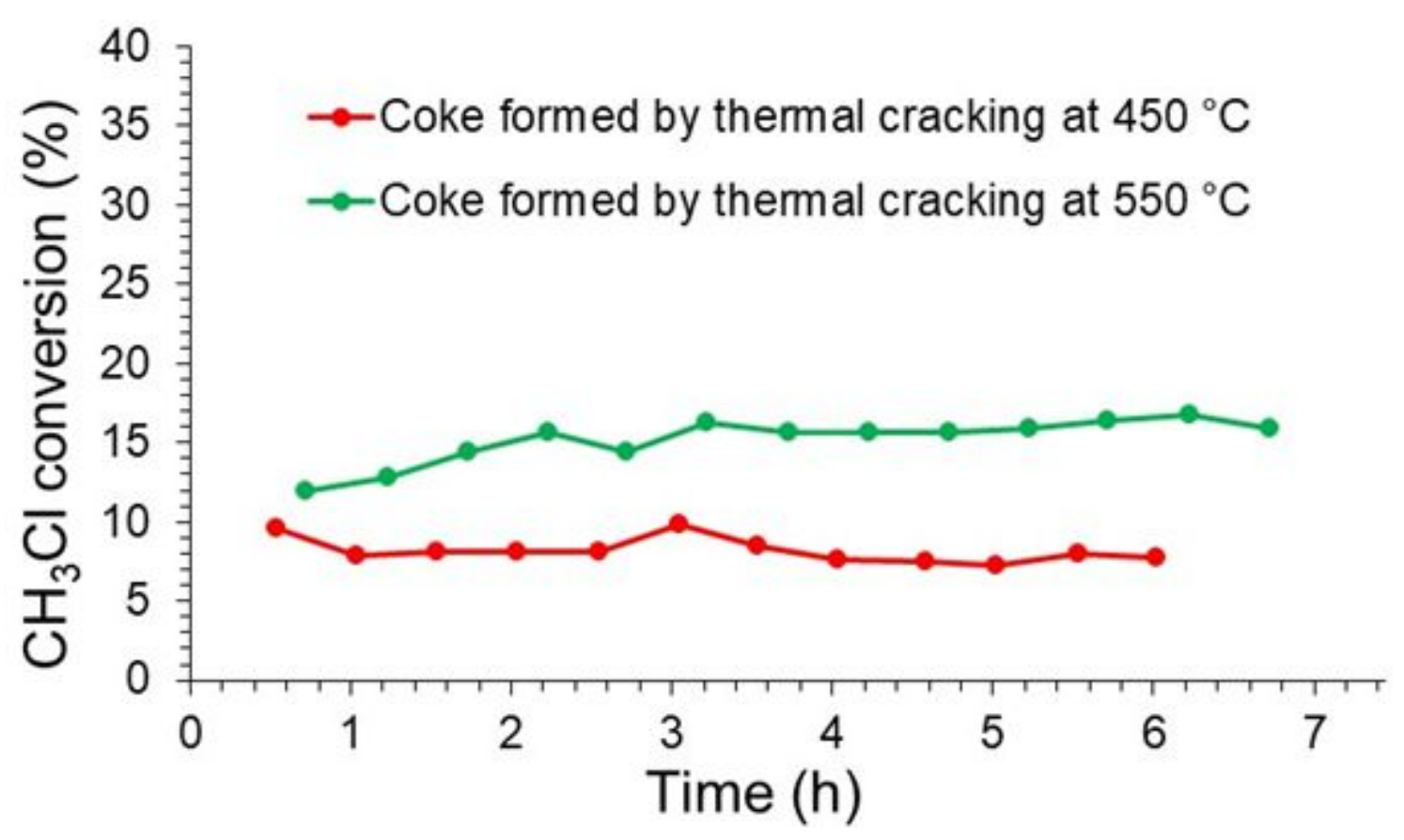

Fig. S1: Conversion of $\mathrm{CH}_{3} \mathrm{Cl}$ at $400{ }^{\circ} \mathrm{C}$ on coke obtained by thermal cracking on $0.8 \mathrm{~g}$ of $\mathrm{SiO}_{2}$ at 450 and $550^{\circ} \mathrm{C}$, at $0.4 \mathrm{Mbar}$ and with a residence time of $0.3 \mathrm{~min}$. 


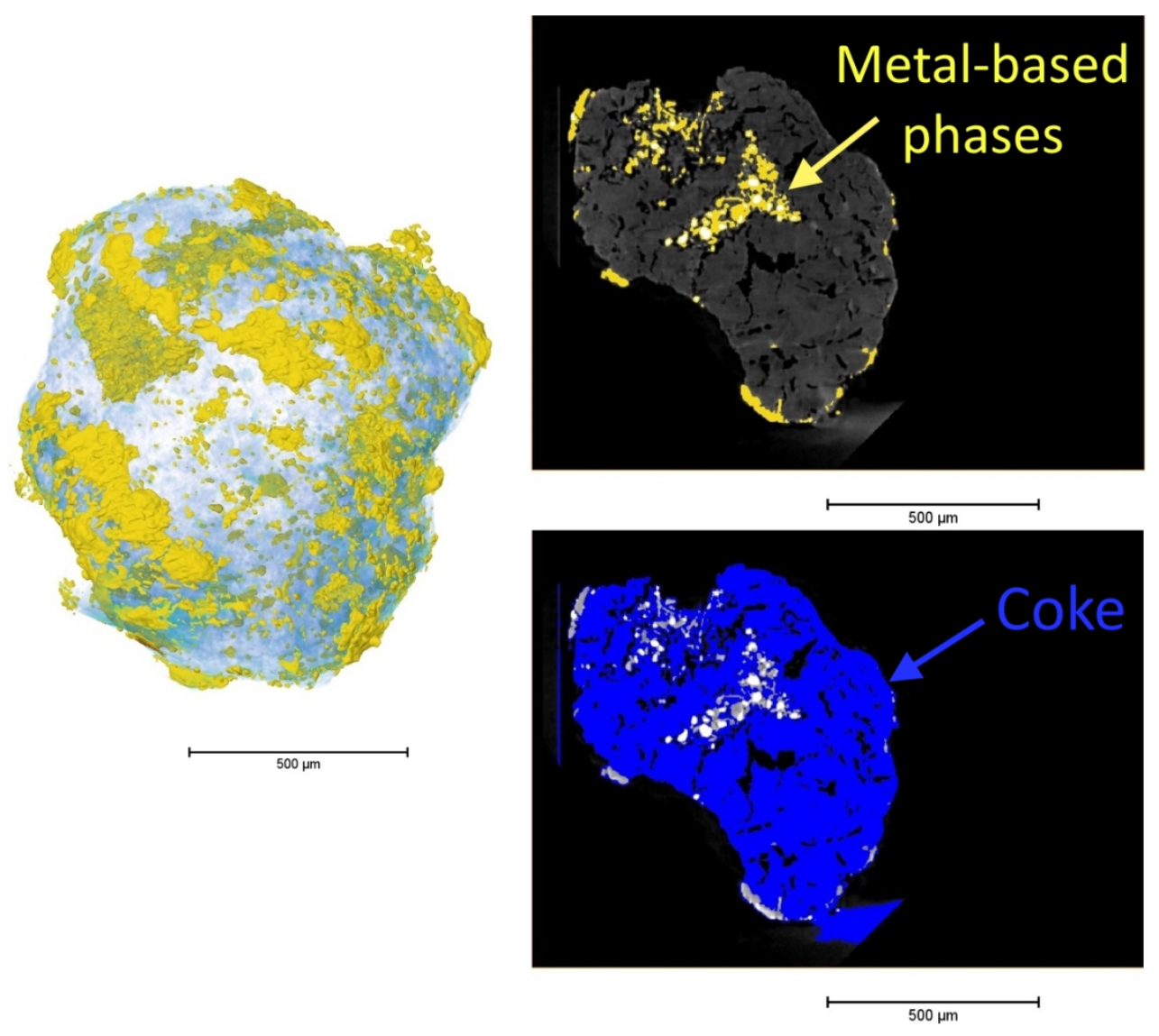

Figure 1

$150 \times 138 \mathrm{~mm}(220 \times 220 \mathrm{DPI})$ 


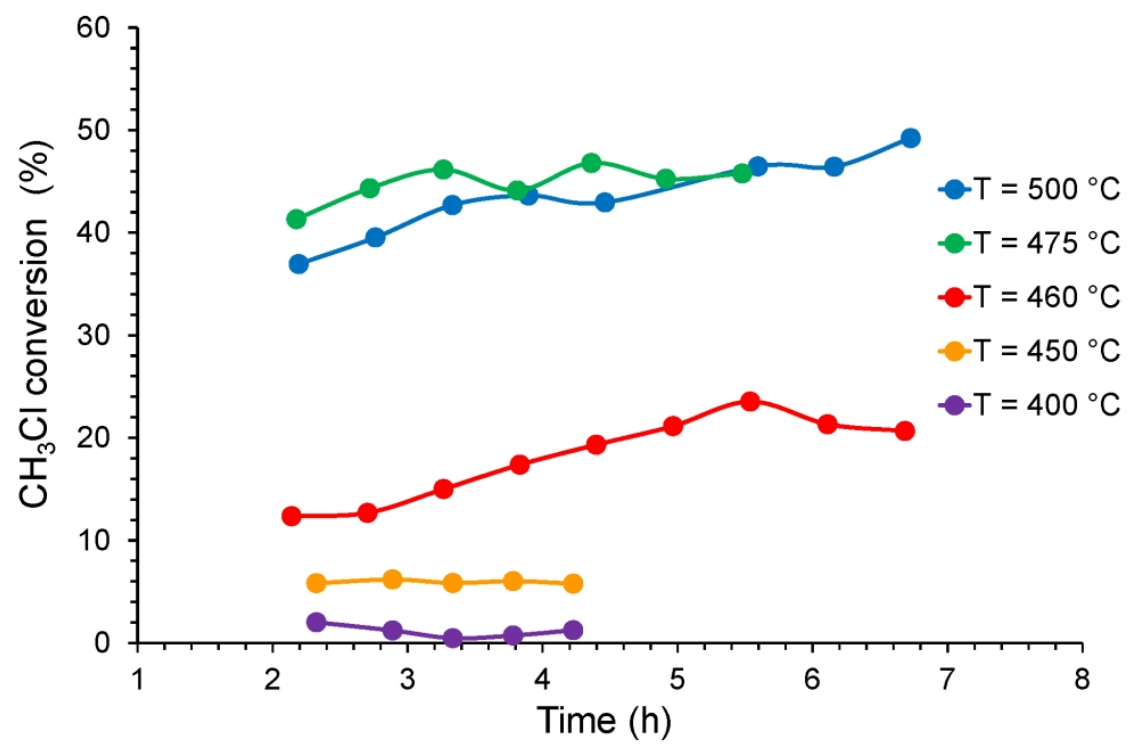

Figure 2

$297 \times 210 \mathrm{~mm}(200 \times 200$ DPI $)$ 


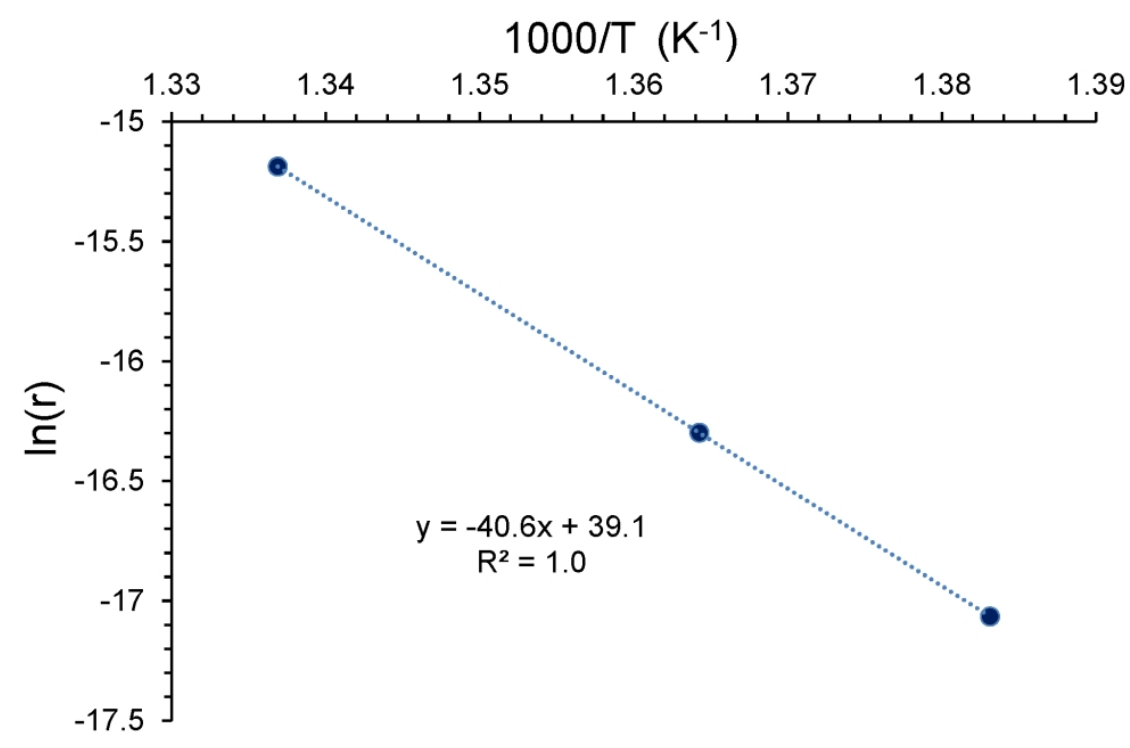

Figure 3

$297 \times 210 \mathrm{~mm}(200 \times 200$ DPI $)$ 


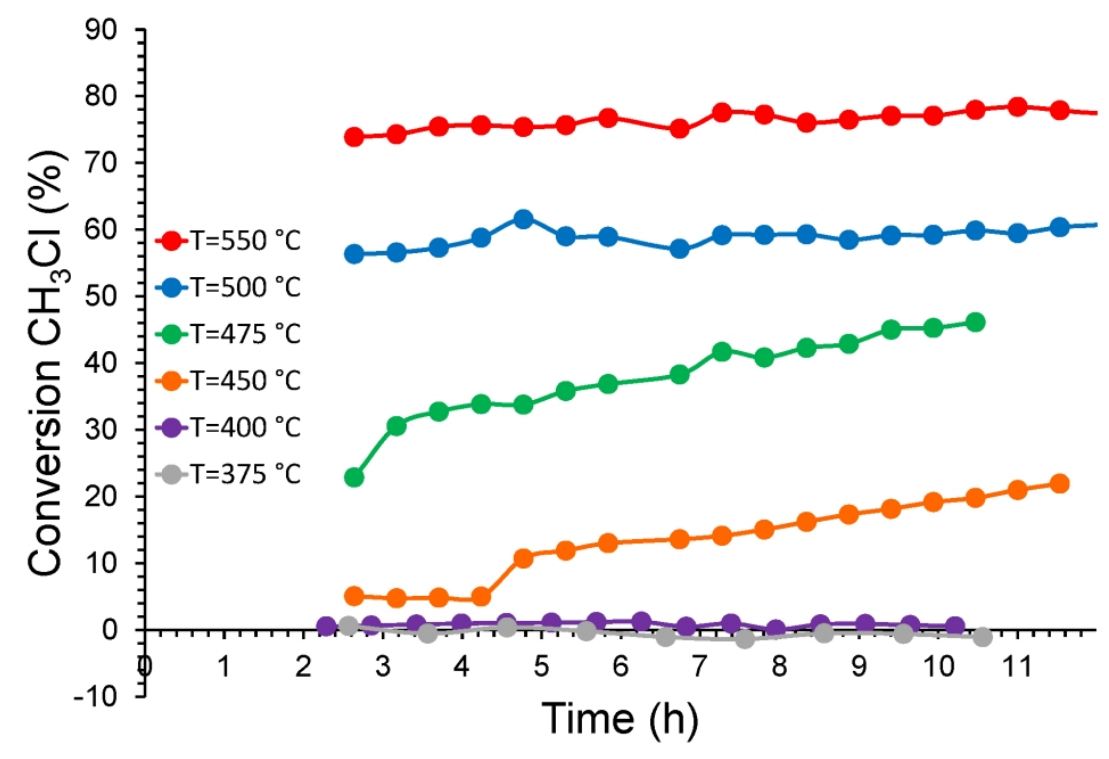

Figure 4

$297 \times 210 \mathrm{~mm}(200 \times 200$ DPI $)$ 


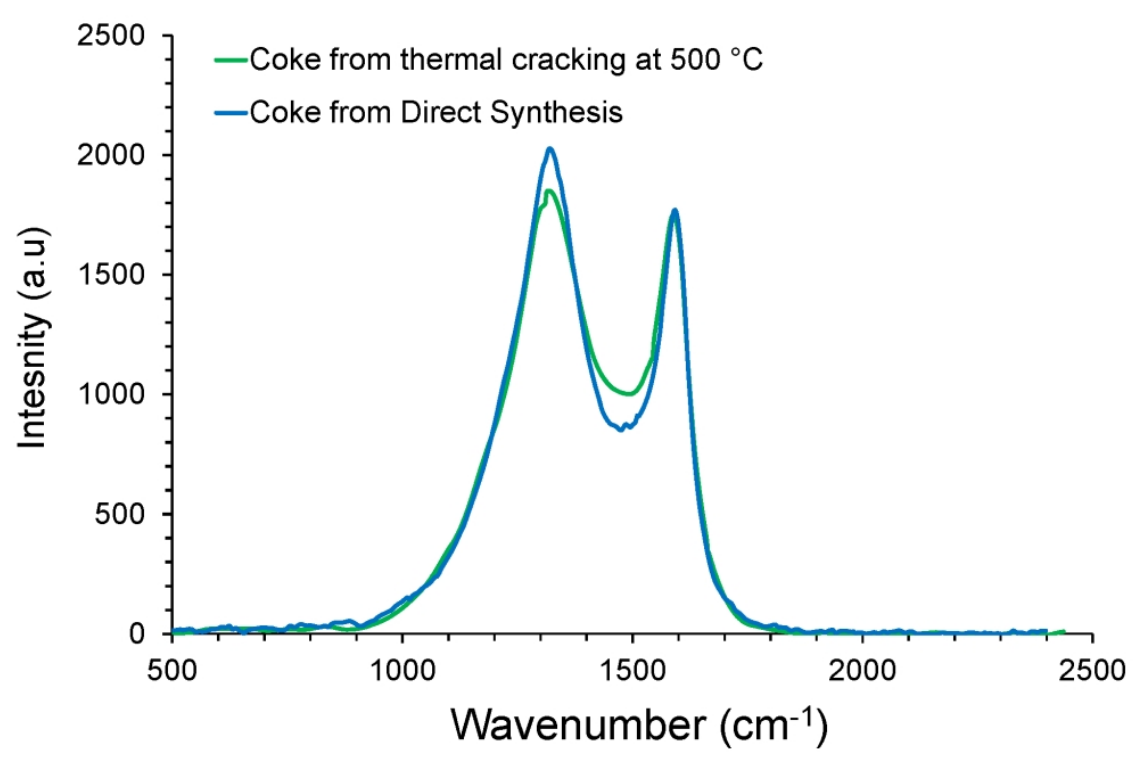

Figure 5

$297 \times 210 \mathrm{~mm}(200 \times 200$ DPI $)$ 


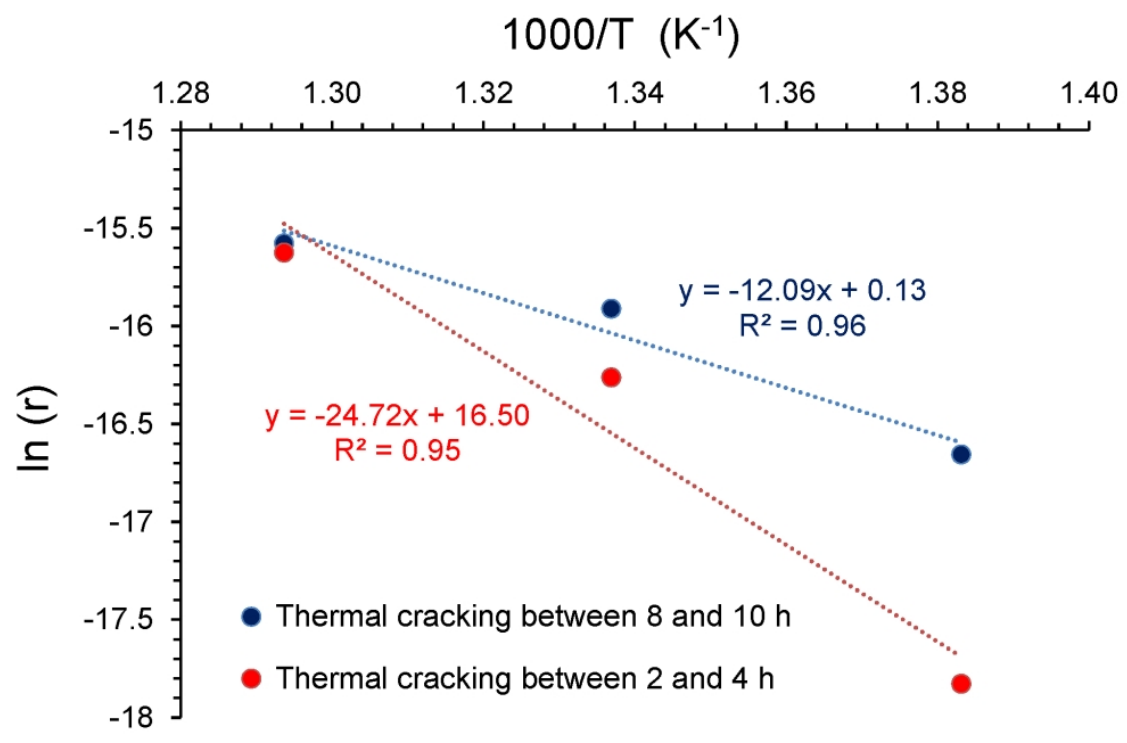

Figure 6

$297 \times 210 \mathrm{~mm}(200 \times 200$ DPI $)$ 


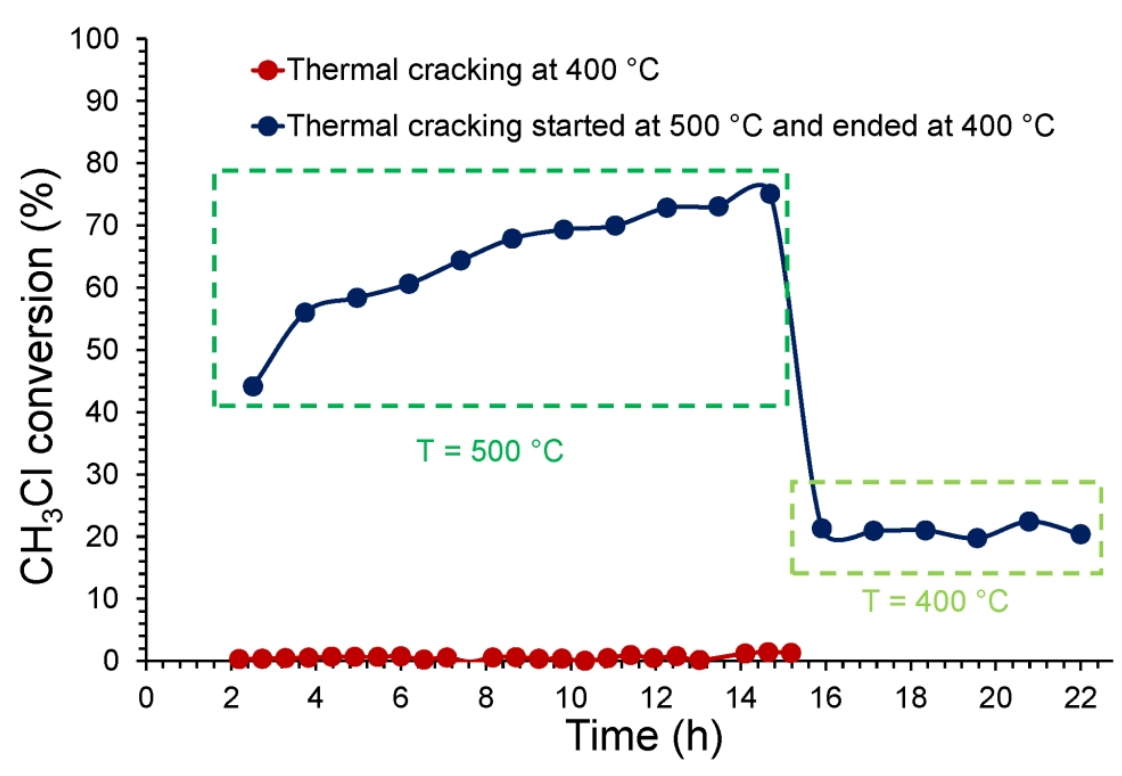

Figure 7

$297 \times 210 \mathrm{~mm}(200 \times 200$ DPI $)$ 


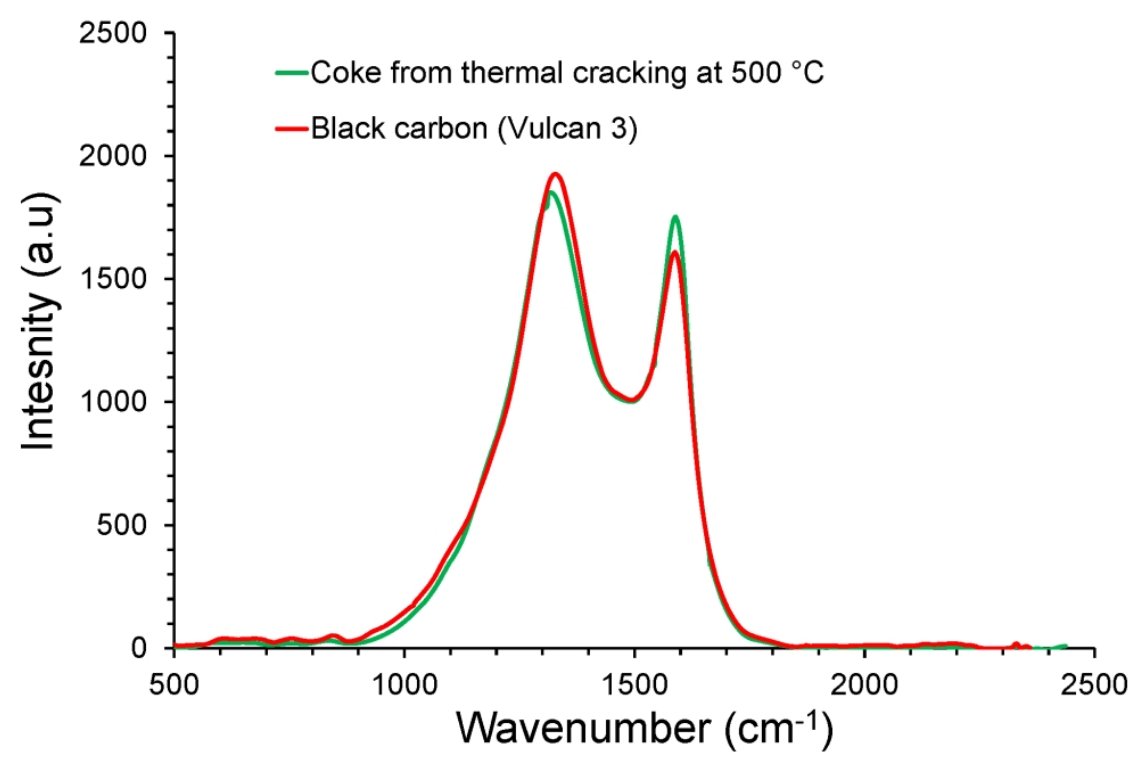

Figure 8

$297 \times 210 \mathrm{~mm}(200 \times 200 \mathrm{DPI})$ 


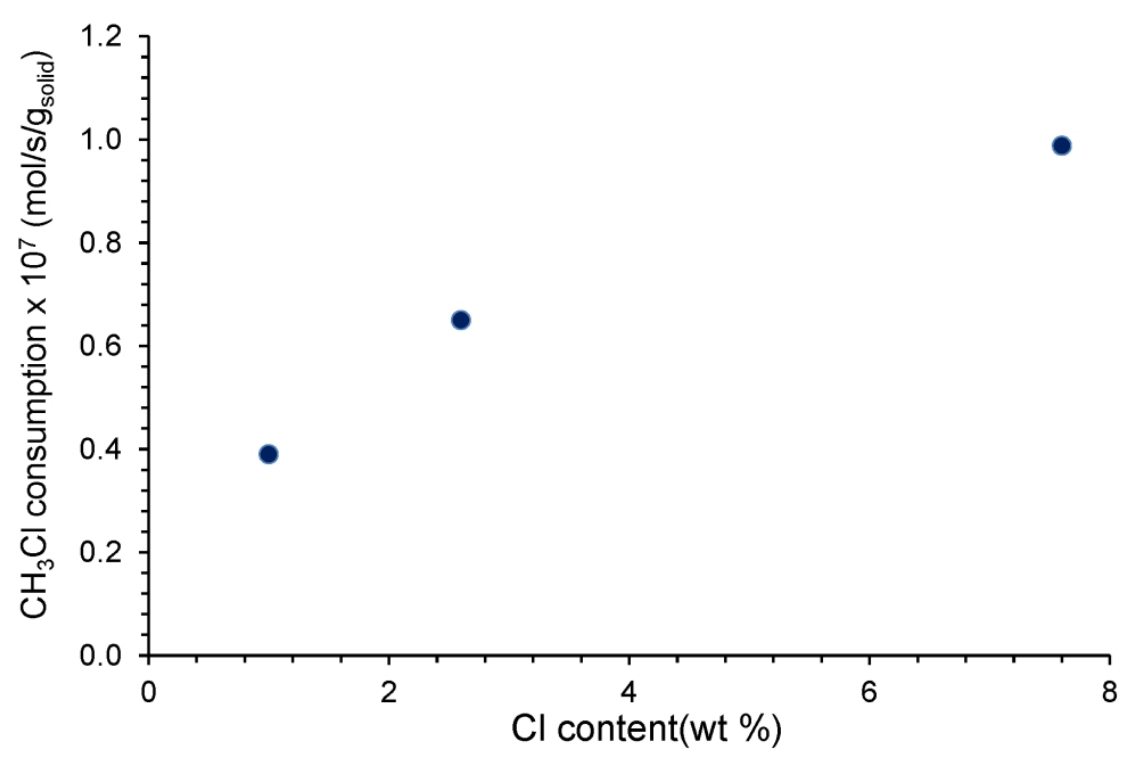

Figure 9

$297 \times 210 \mathrm{~mm}(200 \times 200$ DPI $)$ 


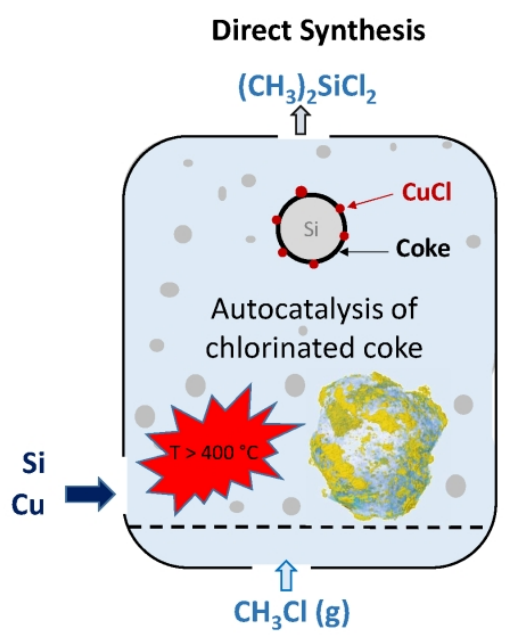

$297 \times 210 \mathrm{~mm}(220 \times 220$ DPI $)$ 